\title{
複数地震動の最大応答層間変形角を包絡して一様化するための剛性設定法 STIFFNESS DETERMINATION METHOD UNIFORMIZING ENVELOPED INTER-STORY DRIFT ANGLE IN MULTIPLE SEISMIC RESPONSES
}

\author{
鈴木 光 雄 ${ }^{* 1}$
}

MitsuoSUZUKI

\begin{abstract}
This paper proposes a stiffness determination method uniformizing inter-story drift angle in seismic response using the closed-form representation of a primary mode. The primary modal shapes for the uniform inter-story drift angle are obtained from seismic response analyses on the 120 models, and shown with number of building stories and dimensionless height as parameters. In the same way, an equation that estimates the uniform inter-story drift angle is shown with building representative height, natural period, and damping constant as parameters. From the above, the stiffness for uniform inter-story drift angle can be easily obtained without repetitive calculations.
\end{abstract}

Keywords : Uniform inter-story drift angle, Stiffness, Primary mode, Control, Shear spring model 一様層間変形角，剛性，一次モード，制御，せん断型モデル

\section{1. はじめに}

振動解析を伴う構造検討では、一般に、検討初期段階で仮定した ベースシア係数および荷重分布から地震荷重を設定し、構造部材の 断面を作成する。次いで、それにより得られた建物の剛性や耐力を 用いて、設計クライテリアを満足するように、地震荷重の再設定、 部材の再設計、建物の剛性、耐力の再設定を行う。以降この手順を 繰り返し、必要に応じて制振装置の設置等を計画し、クライテリア を満足させる。

設計クライテリアとして、一般に層間変形角、部材応力状態、部 材塑性率等の制限が挙げられる。このうち、層間変形角は建物全体 の基本的な振動性状に直接的に関わり、一般的には、層間変形角の クリイテリアを主要な目標として構造部材の断面、強度を設定する ことになる。近年は制振装置の採用が増え、オイルダンパーや鋼材 ダンパー等の制振装置による層間変形角の制御について様々な方 法が提案されている例えば 1)、2)。ただしダンパーの設置では、平面計 画上で箇所数が限定されたり、配置位置が偏在せざるを得ない等で 十分に対応できない場合があり、基本的にはエネルギー吸収を目的 にした減衰向上が主目的となり、変形の制御は補助的となることが 多いものと考えられる。振動性状に関わる建物の質量、剛性、減衰 のうち、層間変形角へ最も影響を与えるものは剛性である ${ }^{3)}$ 。制振 効果が限定的な場合、建物剛性で可能な限り層間変形角の制御を行 い対応不足分を制振装置で対策する方法が現実的であるものと考 えられる。このため、本論では、層間変形角の制御として、建物剛 性による制御を基本方針とする。

建物剛性による層間変形角の制御について、文献 4 ではSRSS 法 で応答值を評価し、一次モードの層間成分に着目して、剛性の閉形
式を用いて繰り返し計算により剛性を算出する設計方法が示され ている。また、文献 5 ではSRSS 法で 1〜3 次モードを用いて、各 階の応答変形が同一になる条件式を適用させ、剛性を求める方法が 示されている。この方法では、繰り返し検討が不要となっているこ とが利点として挙げられる。これは、固有周期およびモード形 (刺 激関数）が既知としていることによるが、採用するモード形につい て一例が示されているのみで、採用すべきモード形については言及 されていない。また、各階の変形量が同一の条件であるため、階高 が異なる場合には、工夫が求められる。

これらは、応答評価に SRSS 法を用いている。SRSS 法はモーダ ルアナリシスに基づくもので、建物の基本的な性状と建物応答を理 解する上で非常に有効な方法である。モーダルアナリシスでは、建 物応答をモード形、固有周期、減衰から求める。建物の質量、剛性 は様々な組み合わせとなるが、応答分布はこれらにより求められる モード形により決定されるものであり、モード形が応答分布の基本 要因となる ${ }^{6)}$ 。よって、本論では質量、剛性の無数の組み合わせに 対し、より少ない情報で応答分布を直接的に表現するモード形で、 層間変形角の一様化の条件を整理する方針とする。

設計実務では、超高層建物や制振構造の設計において、時刻歴応 答解析による安全性確認が求められる。SRSS 法と異なり、時刻歴 応答解析の検討では、スペクトルの異なる複数の地震動の検討が求 められ、また、一次モードと高次モードの同時性による応答のばら つきが大きいこと等の特徵がある。このうち後者に関しては、モー ダルアナリシスの結果と時刻歴応答解析の結果に大きな乘離がみ られる場合がある (3 章参照)。近年では、計算機能力も向上し、地 震応答解析も比較的容易になっている。このことを踏まえ、本論で 
は、時刻歴応答解析結果をもとに検討を行う。ただし、地震応答に おける一次モードの影響が大きいことには変わりなく、剛性の設定 においては文献 4，5 と同様に本論でも一次モード形を利用する。

振動時に各層の応答分布が一様状態で同時に最大応答值に達す ることは理想的な状態の一つと考えられる。これは、極端に剛性の 低い層が存在して部分層崩壊するような状況を防ぐことができ、ま た、建物全体として各層が均等に効率よく減衰効果を発揮できるも のと考えられるからである。一方、現状の設計実務においては、振 動解析を伴う場合、複数地震の応答結果を包絡するように地震力を 設定し、その状態で部材設計を行うとともに、剛性率で建物の強度 バランスを間接的に評価する等の方法が一般に行われている。地震 応答の同時性を考えると、上記の通り必ずしも理想的な検討方法と は言えないが、複数地震動の最大応答を包絡して評価する方法はこ れまでの知見をもとに確立されたものと考えられ、簡便な耐震性能 評価法として有用である。このため、本論では複数地震動の応答を 包絡した最大応答層間変形角を一様にすることを目標とした。この 方法で検討した結果では、7 章に示される通り結果的に多くのケー スで単一地震動の最大応答変形角一様化傾向の向上にもつながり、 比較的理想的な状態を実現できているものと考えられる。

以上より、本論では、複数地震動の最大応答を包絡した最大応答 層間変形角が一様となる建物の設計を目標とする。そのために、時 刻歴応答解析結果を用い、一次モードの閉形式で岡性調整を行い、 多くの解析結果をもとに一次モード形の形状設定を試みる。また、 同時に最大応答值についても考察を行う。これらの結果を用いて、 設計初期において、繰り返し計算を行わずに、目標性能に応じた建 物剛性を設定する方法を提示する。なお、建物の階数、固有周期に ついて広範囲の特性を整理すること目的としており、建物モデルは 最も基本的なせん断型モデルとし、制振構造を想定して構造体は弾 性とし、制振効果は簡易な剛性比例型減衰で評価する。また、採用 する地震動は設計実務で用いられているものとする。

\section{2. 一次固有モード逆問題の閉形式}

$n$ 質点のせん断型モデルを考え、 $j$ 層の質量、せん断岡性を $m_{j}$ 、 $k_{j}$ 、質量マトリクス、剛性マトリクスを $\mathbf{M} 、 \mathbf{K} 、 s$ 次の固有円振動 数、固有モードベクトルを $\omega^{(s)} 、 \mathbf{u}^{(s)}$ とする。このモデルの固有值 問題は(1)式となる。右上添字の括弧内はモード次数を示す。

$$
-\omega^{(s)^{2}} \mathbf{M} \mathbf{u}^{(s)}+\mathbf{K} \mathbf{u}^{(s)}=\mathbf{0}
$$

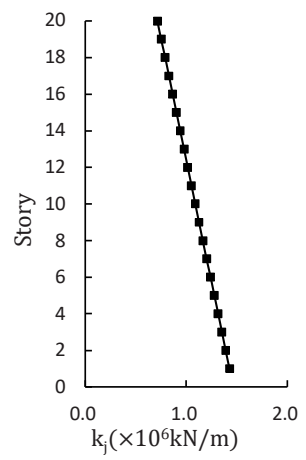

Fig. 1 Initial stiffness

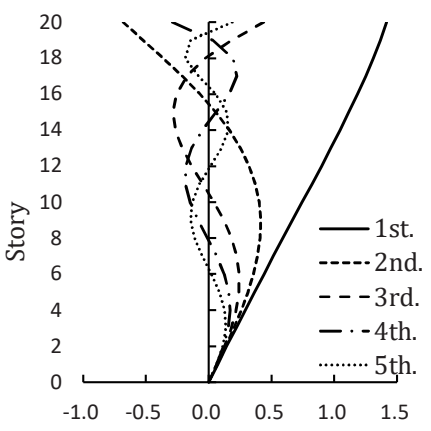

(a) Participation function

Fig. 2 Mode shapes

(1)式を $k_{j}$ について整理すると下式の通りとなる。

$$
k_{j}=\left(\omega^{(s)^{2}} \sum_{l=j}^{n} m_{l} u_{l}^{(s)}\right) /\left(u_{j}^{(s)}-u_{j-1}^{(s)}\right)
$$

$s=1$ の場合 (2)式は、一次固有モード逆問題に対する閉形式で ある。文献 4 では、モーダルアナリシスの検討結果に基づいて、 目標とする一次のモード形状を設定して剛性を算出し、繰り返し 計算により目標とする応答值を実現する方法が示されている。

\section{3. モーダルアナリシスと時刻歴応答解析}

モーダルアナリシスと時刻歴応答解析について解析例をもとに 確認する。解析モデルは固有周期 2.4 秒の 20 層のせん断型モデル で、各層の重量は $10,000 \mathrm{kN}$ 、剛性は最上部を最下部の $1 / 2$ として各 階を線形補間して設定した (Fig.1)。Fig.2に 1～5 次の刺激関数と、 その層間成分を示す。

建物は弾性、減衰は剛性比例型で減衰定数 $2 \%$ 、入力地震動は El Centro $1940(\mathrm{NS}) 、$ 最大速度 $0.5 \mathrm{~m} / \mathrm{s}$ とする。Fig.3 に時刻歴応答解析に よる最大応答層間変形と、モーダルアナリシスによる二乗和平均 $(\mathrm{SRSS}) 、$ 絶対值和 $(\mathrm{ABS}) 、$ 完全二次結合 $(\mathrm{CQC})$ の層間変形を示す。

時刻歴応答結果と SRSS 法、CQC 法では、下層から中層部で時 刻歴応答結果が上回り、上層部では SRSS 法および CQC 法が上回 っている。ABS 法では、時刻歴応答結果を大きく上回る結果であ る。いずれも、最上部の応答は大きな差異が生じている。これは、 Fig.2(b)に示されるように、層間成分に関して最上部では一次モー ドに比べ高次モードがかなり大きくなっており、時刻歴応答におけ る各高次モードの応答が一次モードの応答に足し合わされるタイ ミングにより、時刻歴応答変形の結果が大きく変動するためである。 時刻歴応答の最大值を安全側に見積もるためには、SRSS 法、 CQC 法を割増しして評価する等の方法を行えば、一般的な構造検 討では安全側の評価が可能といえる。しかし、本論で目的とするの は、各層で一様な応答状態を目指し、性能の向上を図るものである。 応答予測精度という点では、応答層間変形における時刻歴応答との 差異が大きいためモーダルアナリシスの適用に難点が生じる。この ような観点で、本論では、直接的に時刻歴応答解析結果を用いるも のとする。

\section{2 質点モデルの固有值解析結果の傾向把握}

ここで、本論の目的とする一次モード成分を制御するための基本 的な性状を把握するために、多質点モデルのうち最も単純な無減衰

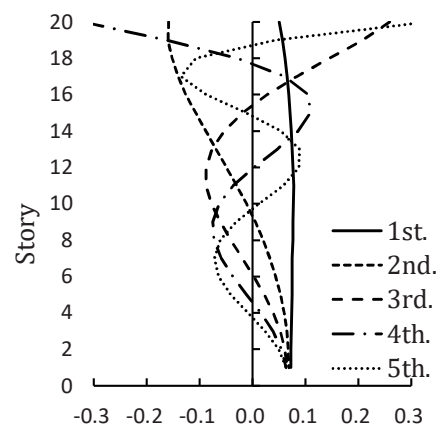
in participation function (b) Inter-story component

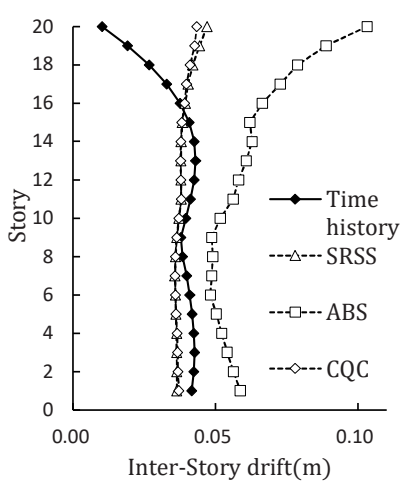

Fig. 3 Inter-story drift 
の 2 質点モデルで各層のモード成分の傾向を調べる。 $u_{1}^{(s)}$ と $u_{2}^{(s)} の$ 比は $\mu=m_{2} / m_{1}$ と $\kappa=k_{2} / k_{1}$ を用いて下式のように表される。

$$
\begin{aligned}
u_{2}^{(s)} / u_{1}^{(s)} & =1 /\left(1-q_{u}\right) \\
q_{u}= & \frac{1}{2}\left(1+\mu+\frac{\mu}{\kappa}\right) \mp \sqrt{\frac{1}{4}\left(1+\mu+\frac{\mu}{\kappa}\right)^{2}-\frac{\mu}{\kappa}} \\
& \left\{\begin{array}{l}
- \text { corresponds to the primary mode } \\
+ \text { corresponds to the secondary mode }
\end{array}\right.
\end{aligned}
$$

Fig.4 に縦軸を下式で示寸モード成分の層間成分比 $\Delta u_{2 / 1}^{(s)}$ 、横軸を кとして示す。ここで、 $\Delta u_{1}^{(s)}=u_{1}^{(s)} 、 \Delta u_{2}^{(s)}=u_{2}^{(s)}-u_{1}^{(s)}$ である。

$\Delta u_{2 / 1}^{(s)} \equiv\left|\Delta u_{2}^{(s)} / \Delta u_{1}^{(s)}\right|$

一次モードの $\Delta u_{2 / 1}^{(1)}$ は、 $\kappa$ と負の相関関係にあり、 $\kappa$ が 1 以下で大 きく変動する。二次モードの $\Delta u_{2 / 1}^{(2)}$ は 1 以上で、 2 層目の成分が 1 層 目の成分より大きくなり、

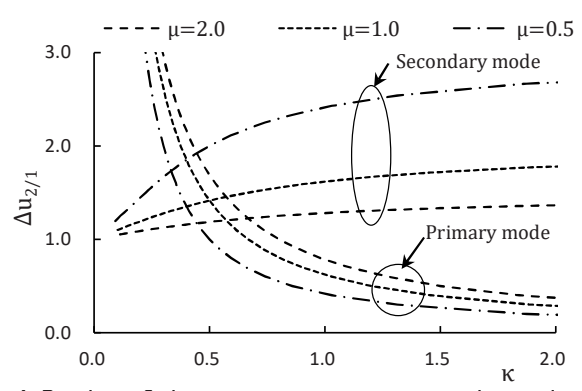

Fig. 4 Ratio of inter-story component in mode shapes

次いで、一次モードと二次モードの影響度を比較するために、各 次の刺激係数 $v^{(s)}$ から定められる刺激関数 $v^{(s)} u_{j}^{(s)}$ で比較を行う。こ の際、地震動の変位応答スペクトルは、一般に固有周期に概ね比例 する形で増加することから、一次モードの周期 $T^{(1)}$ に対する各次の 周期比を $T^{(s / 1)}\left(\equiv T^{(s)} / T^{(1)}\right)$ とし、各次の刺激関数 $v^{(s)} u_{j}^{(s)}$ に $T^{(s / 1)}$ 掛けて一次モードに対する高次モードの影響を考慮する。これらの 刺激関数に対して SRSS 法を適用させると、各層の層間成分は (6) 式により求められ、一、二層目の層間成分の比は(7)式となる。

$$
\begin{aligned}
& \Delta_{p} u_{j}=\sqrt{\left(v^{(1)} \Delta u_{j}^{(1)}\right)^{2}+\left(v^{(2)} \Delta u_{j}^{(2)} T^{(2 / 1)}\right)^{2}} \\
& \Delta_{p} u_{2 / 1}=\Delta_{p} u_{2} / \Delta_{p} u_{1}
\end{aligned}
$$

Fig.5 に $\Delta_{p} u_{2 / 1}$ と $\Delta u_{2 / 1}^{(1)}$ について、横軸を $\kappa$ とてて示す。一次モード の卓越性により、ほぼ、一次モードの $\Delta u_{2 / 1}^{(s)}$ に類似した傾向である ことが読み取れる。ここでは、SRSS 法の結果を示したが、絶対值 和の結果も同様な傾向である。

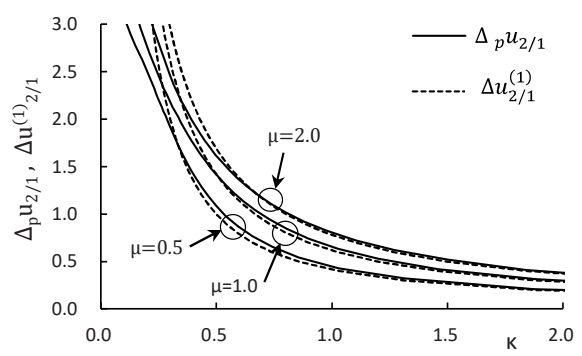

Fig. 5 Ratio of inter-story component in SRSS and mode shapes

これらの結果より、固有周期に概水比例して増加する変位応答ス ペクトルの地震動では、 $\kappa$ に対する一次モードの層間成分比と高次 モードを含めた層間成分比は同様に、負の相関関係となる応答であ
ることがわかる。剛性比により一次モードの層間成分を調整すれ ば、全体応答の増減を制御できるものと考えられる。実際の地震動 の時刻歴応答解析の結果も $\Delta_{p} u_{2 / 1}$ と同様な傾向を示すものと考え られる。ただし、 $\Delta_{p} u_{2 / 1}$ の傾向は曲線状で非線形である傾向を考え ると、時刻歴応答解析結果の層間変形を一様（Fig.5 の縦軸 1.0 に対 応）とするためには、応答結果を確認しながらんを繰り返し調整す る必要がある。

次に、一次モードの $\Delta u_{2 / 1}^{(1)} と \Delta_{p} u_{2 / 1}$ の関係において、質量比 $\mu$ の影 響について確認する。Fig.6 に縦軸を $\Delta_{p} u_{2 / 1}$ 、横軸を $\Delta u_{2 / 1}^{(1)}$ とし、 $\mu=$ 2.0,1.0,0.5の関係を示す。 $\Delta u_{2 / 1}^{(1)}$ が 3.0 以下では $\mu$ の影響が小さい。一 般的な構造では、 $\Delta u_{2 / 1}^{(1)}=0.5 \sim 2.0$ 程度と考えられ、例えば $\mu=1.0$ と して評価した $\Delta u_{2 / 1}^{(1)} と \Delta{ }_{p} u_{2 / 1}$ の傾向は、 $\mu=2.0 \sim 0.5$ の範囲において も適用できるものと考えられる。以上より、本論では等質量を基本 として、振動性状の検討を行う。

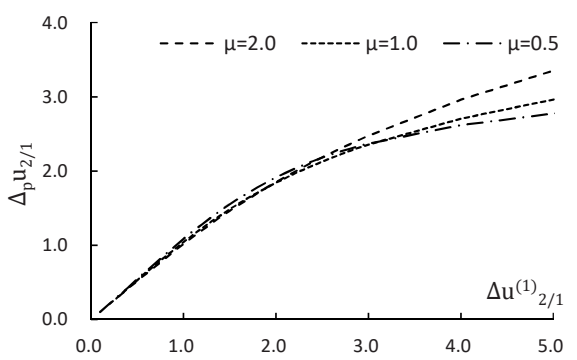

Fig. 6 Relations of inter-story component ratio between SRSS and mode shapes

\section{5. 目標とする応答層間変形分布を実現する剛性制御法}

目標と寸る応答層間変形分布を ${ }_{t g} \Delta d_{j}$ とし、時刻歴応答解析結果 の各層の最大応答層間変形 $\Delta y_{j}$ を用い、 ${ }_{g} \Delta d_{j}$ に対する各層変形 $\Delta y_{j}$ の 比を ${ }_{d y} p_{j}\left(\equiv \Delta y_{j} /{ }_{t g} \Delta d_{j}\right)$ とする。その逆数を $\Delta u_{j}^{(1)}$ に掛け更新された ${ }_{u p d} \Delta u_{j}^{(1)}$ を下式のように設定する。

$$
{ }_{u p d} \Delta u_{j}^{(1)}=\Delta u_{j}^{(1)} /{ }_{d y} p_{j}
$$

この設定は文献 4 と同様であり、文献 4 ではモーダルアナリシ スの結果を用いているが、 3 章の解析例で示したような精度向上の 観点から本検討では時刻歴応答解析結果を用いる。

以下に、時刻歴応答解析結果の応答層間変形をもとにして、目標 とする応答層間変形分布を実現する建物剛性の制御方法を示す。

Step0 建物諸元（質量、剛性、減衰）、建物固有周期および、目 標とする層間変形分布を設定する。

Step1 固有值解析および時刻歴応答解析を行う。

Step2 応答結果をもとにした ${ }_{u p d} \Delta u_{j}^{(1)}$ から、(2)式で建物剛性を設 定し、Step1に戻り、以降Step 1,2 を繰り返し、目標とする 応答層間変形分布に達した時点で演算を終了する。

\section{6. 剛性制御による解析結果}

3 章の解析例と同じ建物、入力地震動の条件で、5 章の剛性制御 方法を試みる。目標応答層間変形分布 $t g \Delta d_{j}$ は各層一定とする。収束 判定条件は、 ${ }_{d y} p_{j}$ の各層の平均值 ${ }_{d y} p$ と ${ }_{d y} p_{j}$ が、下記条件を全層で満 足した時とする。

$$
\left|1.0-{ }_{d y} p_{j} / \overline{{ }_{d y} p}\right| \leqq 0.02
$$


解析結果を Fig.7(a)に示す。初期剛性の応答状態から各層一様な 応答へ変化している。収束までの繰り返し回数は 5 回であった。ま た、制御後の剛性を用いて SRSS 法で評価した結果は、時刻歴応答 解析結果と差異が生じており、一様な応答と評価するのは困難であ る。

最大応答層間変形角が発生する時刻を Fig. 8 示す。制御後は初期 の状態から最大となる時刻が変化している。制御後の最大層間変形 角が発生する代表的な時刻の層間変形角を Fig.7(b)に示す。異なる 時刻での応答を制御できていることから、複数の地震動が連続して 発生するものと考えることで、同様に複数の地震動の最大応答層間 変形を包絡するように制御できるものと推察される。

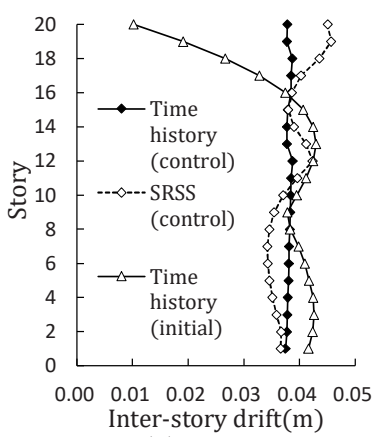

(a) Max imum

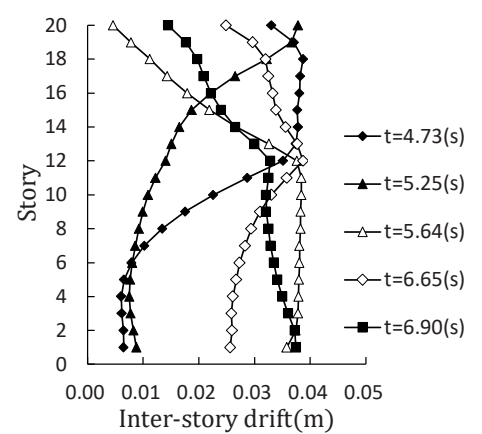

(b) In each time
Fig. 7 Inter-story drift (El Centro)

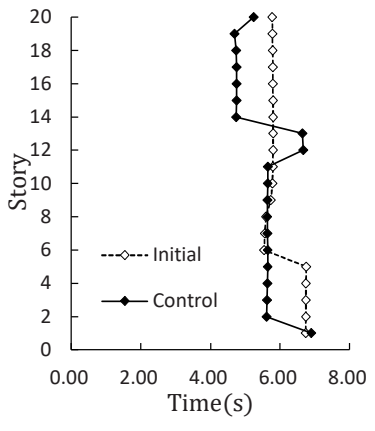

Fig. 8 Time of occurrence of maximum inter-story drift (EI Centro)

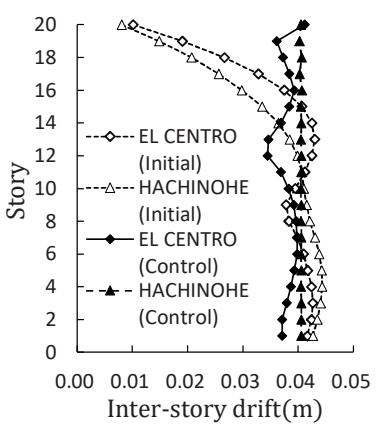

Fig. 9 Maximum Inter-story drift (EI Centro and Hachinohe)
次に、入力地震動を El Centro1940(NS) と Hachinohe(NS)の 2 波 (最 大速度 $0.5 \mathrm{~m} / \mathrm{s}$ ) の応答に対して制御を行う。剛性を制御するために 用いる応答值 $\left(5\right.$ 章の $\left.\Delta y_{j}\right)$ は、 2 波の時刻歴応答による最大応答層 間変形を包絡したものとする。Fig.9 に制御前と制御後の最大応答 層間変形を示す。複数地震動を包絡する形での制御が可能であるこ とが確認される。この結果では、制御前は 1～10 層で Hachinohe (NS) の最大応答層間変形が El Centro1940(NS)の応答を上回っているが、 制御後では 1〜19 層で Hachinohe (NS)の応答が El Centro1940(NS)の 応答を上回る結果となっている。

制御後の建物剛性と一次モードの層間成分を Fig.10 に示す。制御 後の結果は El Centro1940(NS)の最大応答を単独で制御した結果と、 El Centro1940(NS) と Hachinohe(NS)の複数の最大応答を包絡して制 御した結果は、建物剛性と一次モードの層間成分共に、比較的似通 った結果となっている。

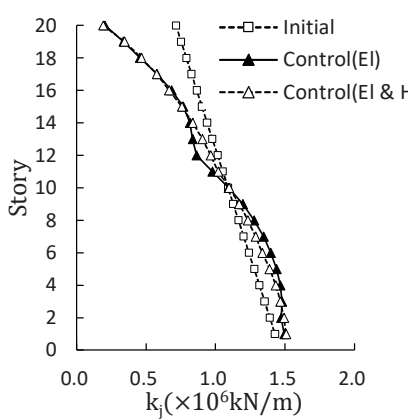

(a) Stiffness

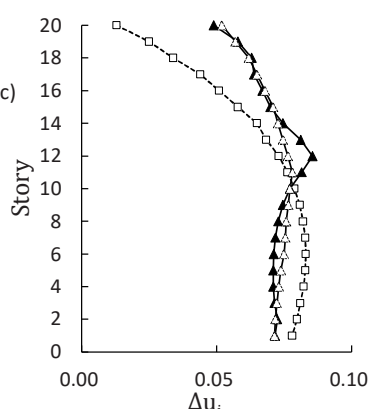

(b) Inter-story component
Fig. 10 Results of control

\section{7.一様な層間変形角となる建物性状について}

本論では、各層の応答変形が一様となる剛性の設定方法を考察す るものである。そのための方法として、5 章で示す方法により、目 標とする層間変形分布の実現が可能であることを確認した。

設計の初期段階で、層間変形角の一様化を目標とし、それを実現 する一次モード形がわかれば、固有周期を設定することにより、(2) 式から剛性を簡単に求めることができる。このため、層間変形角の 一様化を目標とする剛性による制御を多数のケースで行い、その結 果得られた一次モードの層間成分がどのような傾向を示すかにつ いて調べる。

対象とする地震動は設計実務を念頭にし、建設省告示第 1461 号 に定められるスペクトルで作成された地震動（以下、告示波）と、 観測地震波(最大速度 $0.5 \mathrm{~m} / \mathrm{s}$ ) の El Centro1940(NS)、Taft1952(EW)、

Hachinohe1968(NS)、およびBCJ-L2を 0.815 倍したものである。告 示波の位相は Hachinohe1968(NS)、JMA-Kobe1995(NS) とする。また、 BCJ-L2 の 0.815 倍は速度応答スペクトルを告示波と同じ設定とし、 告示波のランダム位相に準じるものとして設定した。

建物のモデルは階数を 5 階、10 階、15 階、20 階、25 階、30 階の 6 種類とし、各層の重量を $10,000 \mathrm{kN}$ 、階高 $\Delta H_{j}$ を $4.0 \mathrm{~m}$ として建物高 さHを設定し、固有周期 $T^{(1)}$ を $0.025 H 、 0.030 H 、 0.035 H 、 0.040 H$ 、 $0.045 H$ の 5 種類を設定する。本論では弾性の鉄骨造を想定し、一般 に固有周期の略算值とされる $0.030 H$ をもとに、やや剛性の高い $0.025 H$ から、ダンパーに期待して高減衰化を図り弾性状態に収め るような建物を想定し $0.045 H$ まで設定したものである。減衰は、剛 性比例型とし一次モードの減衰定数 $h^{(1)}$ は0.02、0.05、0.07、0.10の 4 種類を設定した。制御前の初期剛性は最上部を最下部の $1 / 2$ とし て各階を線形補間して設定した。

制御目標は層間変形角の一様化とし、(9)式により収束判定を行 った。Fig.11(a)に 20 層建物の $h^{(1)}=0.05$ のきの、 $T^{(1)}=2.0 \sim 3.6(s)$ の制御前後の最大応答層間変形角を示す。層間変形角は、上階で収 束性が悪いことが確認されるが、これは、上階ほど高次モードの影 響が高いためと考えられる。Fig.11(b)に制御前後の各階剛性を示す。 上層で岡性が低くなり、中層から下層で剛性が増える傾向となって いる。なお、制御前後で各階の剛性の変動はあるが、5 章の Step2 の(2)式に用いる固有円振動数は制御前後で同じ值を用いているの で、固有周期に変動はない。

このような形で建物階数 6 種類、固有周期 5 種類、減衰定数 4 種 類の合計 120 ケースについて、地震動 6 波の 720 回の振動解析を行 
い、一様変形応答となる剛性の制御を行った。

この解析では、地震動 6 波の最大応答值を包絡するように制御を 行ったものであり、制御対象の地震動は、最大応答を示すものに限 られる。制御対象以外の個々の地震動の応答も含め、制御前後で一 様変形の程度にどのような変化が生じたかについて、各層の最大応 答層間変形角の平均と標準偏差の比で示される各層に関する変動 係数 $\mathrm{CV}$ で評価した（付録 $\mathrm{A} ）$ 。CV が小さいほど、一様変形の程度 が高いと考えられる。制御前に対する制御後の CV の比が 1 を下回 るケースは、720 回中 707 回であり、ほとんどのケースで、一様変 形となる傾向が確認されている。この結果は、初期の剛性設定およ び対象地震動により変わるものであるが、本検討地震動に対しては 概小応答性状が向上したと捉えられる。

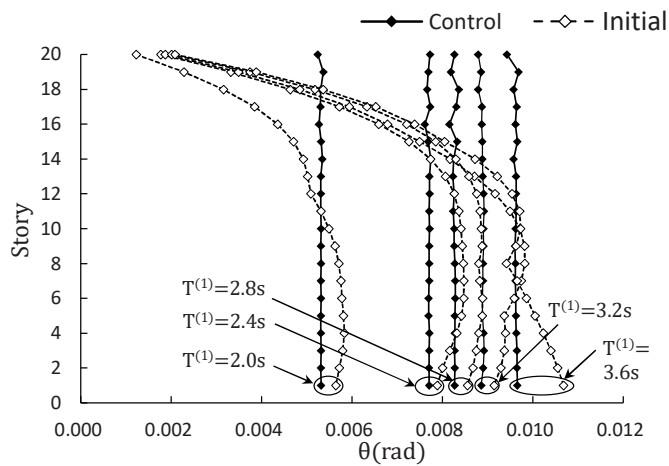

(a) Inter-story drift angle

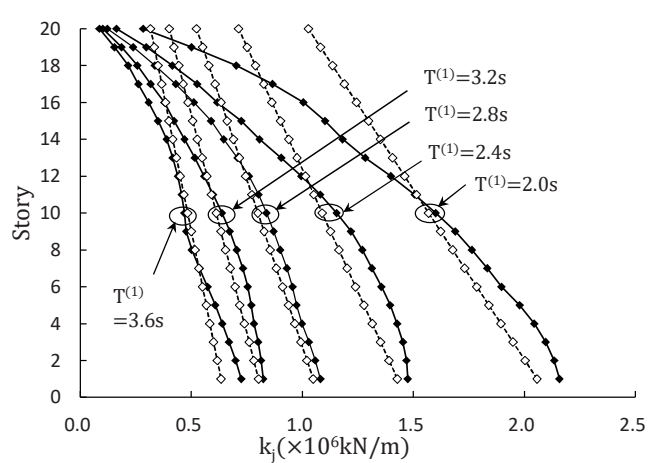

(b) Stiffness

Fig. 11 Comparison between before and after control (20-story)

これらの結果より、一様変形応答時の一次モードの層間成分およ

び、代表変形について以下に考察する。

(1) 一次モードの層間成分

以上の解析結果から得られた一次モードの層間成分を、最大值が 1.0 となるように正規化した一次モードの層間成分 $\Delta u_{j}^{(1)} 6$ 種類の 階数の建物ごとに Fig. 12 に示す。縦軸は建物最高高さHが 1.0 とな

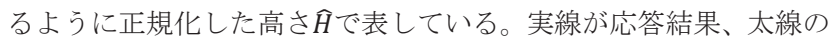
点線が応答結果の平均を示し、破線は初期設定の一次モードの層間 成分 $\Delta u_{j}^{(1)}$ である。制御後の $\Delta u_{j}^{(1)}$ の各層のばらつきは比較的小さく、 固有周期および減衰定数が $\Delta u_{j}^{(1)} に$ 与える影響は限定的である

次に 6 種類の階数の建物ごとに、一次モードの層間成分 $\Delta u_{j}^{(1)}$ の 各層の平均值が 1.0 になるように、 $\Delta u_{j}^{(1)}$ に倍率を掛け正規化する。 その結果を Fig.13 に示す。上層で平均值 1.0 より小さく、中下層で 1.0 より大きくなっている。平均值からの差は、概ね建物階数が増 えるほど大きくなる傾向となる。これは、階数が増えるほど上層部

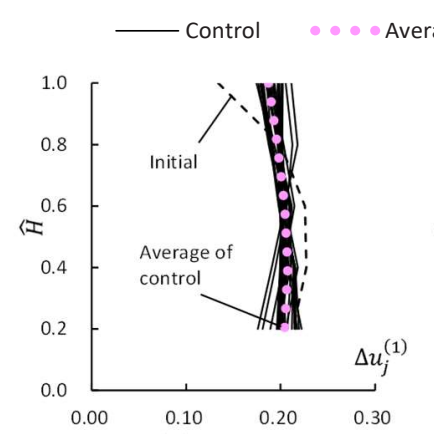

(a) 5-story

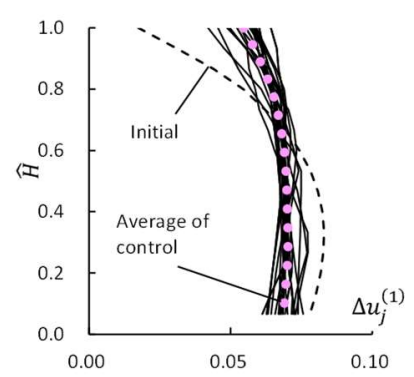

(c) 15-story

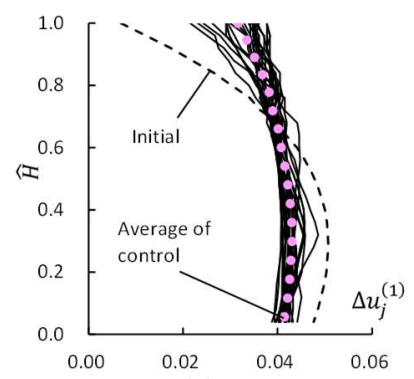

(e) 25-story

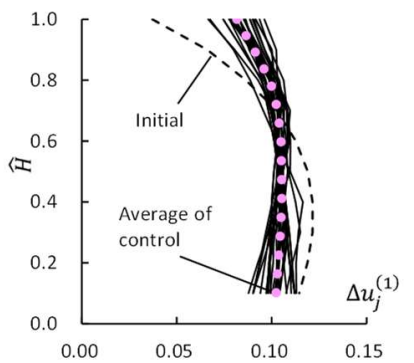

(b) 10-story

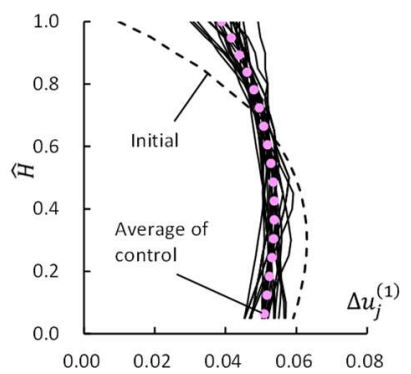

(d) 20-story

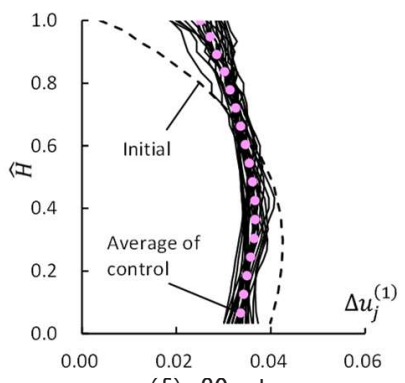

(f) 30-story
Fig. 12 Inter-story component in normalized primary mode

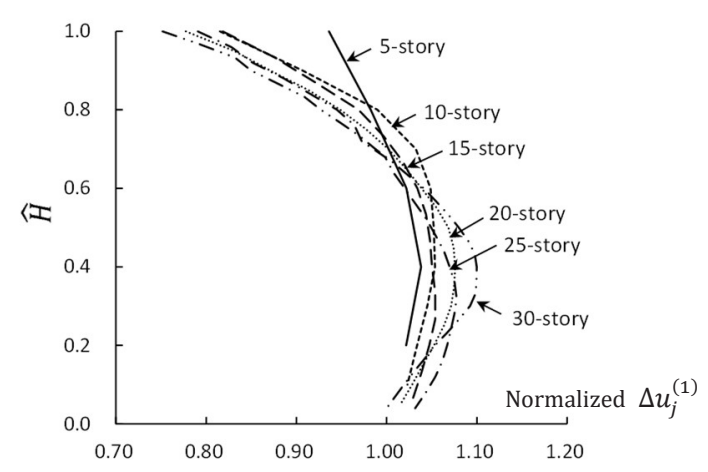

Fig. 13 Normalized inter-story component in primary mode

では高次モードの影響で応答が増える傾向があり、一次モードの成 分を低下させる必要があることに起因しているものと考えられる。

このような高次モードの影響を踏まえ、一次モードの形状 $\hat{u}_{j}^{(1)}$ を下式のように設定する。ここでは、パラメータとして階数 $n$ 、正 規化した高さ $\widehat{H}_{j}$ を採用している。

$$
p^{(1)}=\widehat{H}_{j}+q_{1} \widehat{H}_{j}^{q_{2}} \sin \left(\pi \widehat{H}_{j}\right)+q_{3}\left(\widehat{H}_{j}-1\right)^{3}\left\{\left(\widehat{H}_{j}-1\right)^{2}-1\right\}
$$
各係数 $q_{1} 、 q_{2} 、 q_{3}$ は以下のようになる。

$$
\begin{aligned}
& q_{1}=\left(-9.1 \times 10^{-5}\right) n^{2}+\left(5.4 \times 10^{-3}\right) n+0.0117 \\
& q_{2}=-0.01 n+1.85 \\
& q_{3}=\left(-4.0 \times 10^{-4}\right) n+0.034
\end{aligned}
$$


(10)式の第一項は、高さ方向に直線状に分布するものでモード層 間成分の勾配が一定の状態を示す。第二項は Fig.13 に示されるよう な中層部から最上部に行くほどモード層間成分が低下寸る効果を 主に表現し、第三項は Fig.13 の中間部から最下部の間でモード層間 成分が膨らむ効果を主に示している（付録 B）。各係数 $q_{1} 、 q_{2} 、 q_{3}$ は階数 $n$ ごとの傾向に合うように適宜設定したものである。

一次モードの層間成分 $\Delta u_{j}^{(1)}$ と (10)式の ${ }_{p} \hat{u}_{j}^{(1)}$ から求めた層間成分 $\Delta_{p} \hat{u}_{j}^{(1)}$ との比較を Fig.14 に示す。

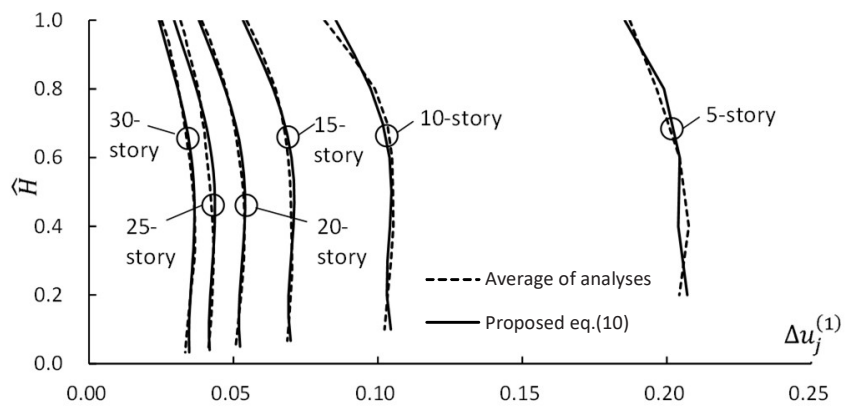

Fig. 14 Comparison between analytical and proposed interstory component in primary mode

$p \hat{u}_{j}^{(1)}$ は、一様な層間変形角を実現する建物剛性を求めるための ものである。(10)式の ${ }_{p} \hat{u}^{(1)}$ を(2)式のuに代入して求められる剛性を ${ }_{p} k_{j}$ とする。

$$
{ }_{p} k_{j}=\left(\omega^{(1)^{2}} \sum_{l=j}^{n} m_{l} \cdot{ }_{p} \hat{u}_{l}^{(1)}\right) /\left({ }_{p} \hat{u}_{j}^{(1)}-{ }_{p} \hat{u}_{j-1}^{(1)}\right)
$$

剛性 ${ }_{p} k$ と、一様変形となるように時刻歴応答解析により制御し た剛性 ${ }_{c} k$ との比 ${ }_{p} k /{ }_{c} k$ を Fig.15 に示す。すべてのケースが $30 \%$ 以内となり、特に上部構造以外の $\widehat{H}_{j}$ が 0.7 以下の範囲では、 $\pm 13 \%$ 以内であり、精度良く評価されているものと考えられる。

${ }_{p} k_{j}$ は、異なる固有周期および、減衰定数の結果の平均をもとに 設定されている。上部で比較的ばらつきが大きいのは、主に減衰定 数 $h^{(1)}$ によるもので、特徴的な変動傾向が確認されている(付録 C)。 上部構造の剛性を、減衰の影響を考慮して補正し精度を向上させる ことも考えられる。しかし、 ${ }_{p} k /{ }_{c} k$ が $\pm 30 \%$ 程度に収まっているこ とから、設計の詳細検討において上部の剛性調整の必要が生じる可 能性はあるものの、取り扱いの簡便化を図り、上部構造の剛性のば らつきについては、付録 C に示すような特段の対応は行わないも のとしている。

(2) 代表変形と層間変形角

(1)では、各層が一様な最大層間変形角となるような一次モード 形について考察した。次に、最大層間変形角の值そのものを求める ための考察を行う。

時刻歴応答解析による各層の最大応答変位 $y_{j}$ を用い、次式で示さ れる建物の代表変位 ${ }^{7)} y_{r}$ を縦軸、固有周期を横軸としたグラフを、 減衰定数ごとに Fig.16 に示す。

$$
y_{r}=\left(\sum_{l=1}^{n} m_{l} y_{l}^{2}\right) /\left(\sum_{l=1}^{n} m_{l} y_{l}\right)
$$

図中に示す実線は最小二乗法による直線回帰式をもとに設定し た下式に示寸近似直線(単位 $\mathrm{m})$ である。

$$
{ }_{p} y_{r}=\left\{-0.06 \ln \left(h^{(1)}\right)-0.02\right\} T^{(1)}
$$

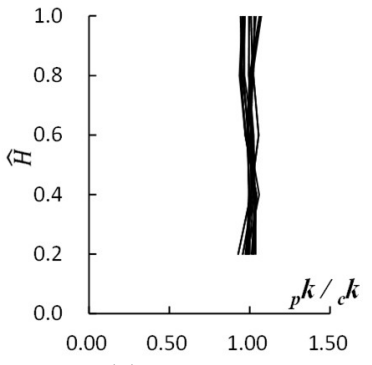

(a) 5-story

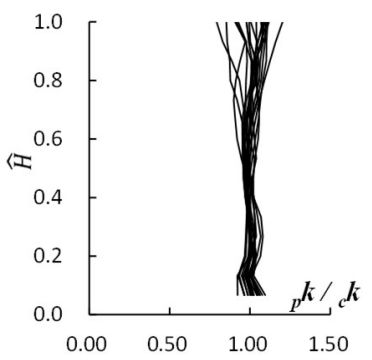

(c) 15-story

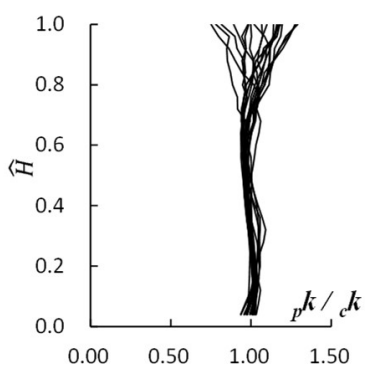

(e) 25-story

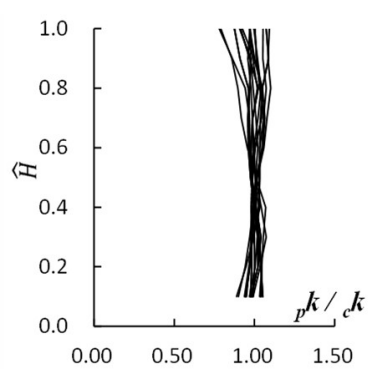

(b) 10-story

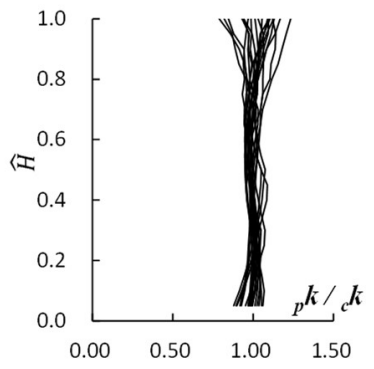

(d) 20-story

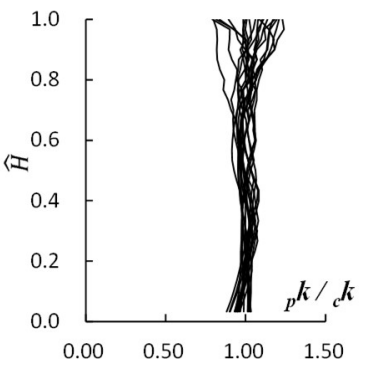

(f) 30-story
Fig. 15 Comparison between analytical and proposed stiffness for uniform inter-story drift angle

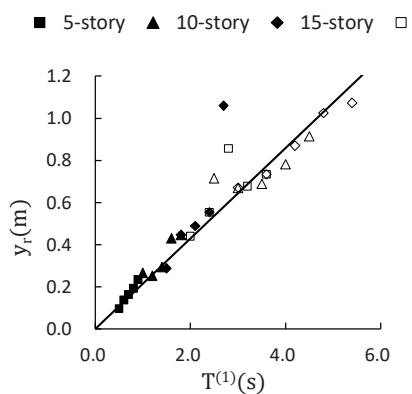

(a) $\mathrm{h}^{(1)}=0.02$

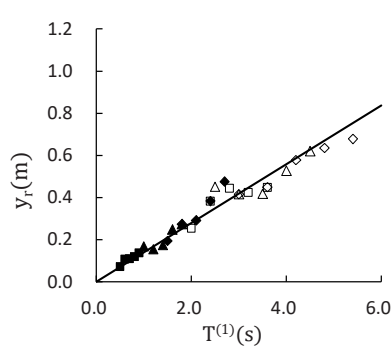

(c) $\mathrm{h}^{(1)}=0.07$

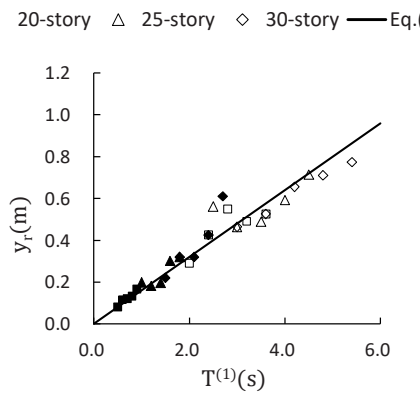

(b) $\mathrm{h}^{(1)}=0.05$

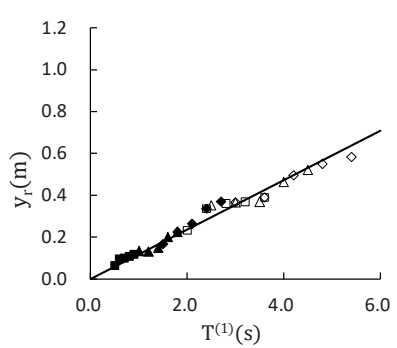

(d) $\mathrm{h}^{(1)}=0.10$
Fig. 16 Representative displacement

各層の層間変形角が完全に一致する場合、建物各層の変形は高さ に比例することになり、代表変位が生じる高さ $H_{r}$ は次式の通りに表 
される。

$$
H_{r}=\sum_{l=1}^{n} m_{l} H_{l}^{2} / \sum_{l=1}^{n} m_{l} H_{l}
$$

このときの層間変形角 $\theta_{r}$ は次式のように表される。

$$
\theta_{r}=y_{r} / H_{r}
$$

$y_{r}$ を(16) 式に示寸直線回帰式により設定した場合の層間変形角 は、固有周期 3.0 秒以下で大きなばらつきを有する（付録 D）。こ れは、Fig.16に示されているように $y_{r}$ のばらつきが大きいことに起 因する。ここでは、2.7 秒付近の特異に乘離しているものを除き、 応答解析結果が+10〜 $-30 \%$ に収まるように補正を行い、下式のよう に層間変形角 ${ }_{p} \theta_{r}$ を設定する。

$$
\begin{gathered}
{ }_{p} \theta_{r}=\left[-p_{\theta} \cdot \tanh \left\{\left(T^{(1)}\right)^{2}-8.0\right\}+p_{\theta}+1\right]_{p} y_{r} / H_{r} \\
p_{\theta}=-0.75 h^{(1)}+0.185
\end{gathered}
$$

これは、すべての応答を包絡するように層間変形角を設定すると、 下限の応答との乘離が大きく精度が劣ることから、設計初期設定の 趣旨に鑑み、ある程度安全側で応答值と差異もそれほど大きくない 範囲で設定することを意図したものである。

このときの層間変形角 ${ }_{p} \theta_{r}$ と、時刻歴応答結果を用いて代表変位 $y_{r}$ から求めた層間変形角 $\theta_{c}$ の比 $\theta_{c} /{ }_{p} \theta_{r}$ をプロットしたグラフを Fig. 17 に示す。応答結果の $90 \%$ 程度が+10〜-30\%に収まっている ことが確認できる。2.7 秒付近で局所的に応答值が大きく乘離して いる理由は、Hachinohe(NS)の応答変位スペクトルが卓越している ためである（付録 E）。2.7 秒付近では、例えば安全側に 1.5 倍して 評価する等の配慮が必要となる。(19)式の補正の影響は Fig.17 と付 録 D の Fig.D1 を参照することにより確認できる。

参考として、本解析で得られたベースシア係数の結果を付録 $\mathrm{F}$ に 示寸。

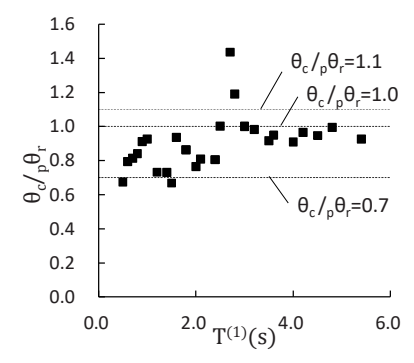

(a) $\mathrm{h}^{(1)}=0.02$

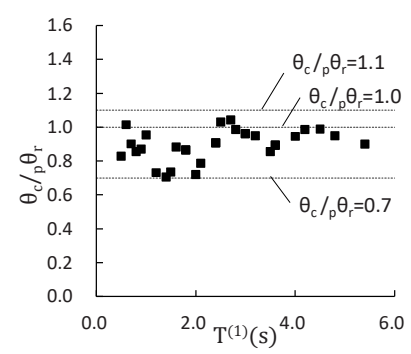

(c) $\mathrm{h}^{(1)}=0.07$

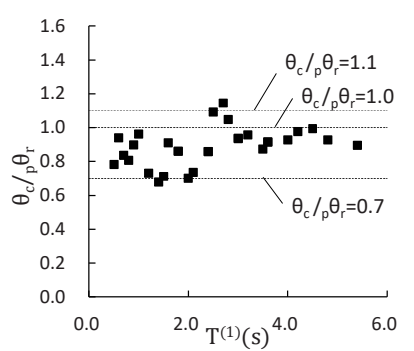

(b) $\mathrm{h}^{(1)}=0.05$

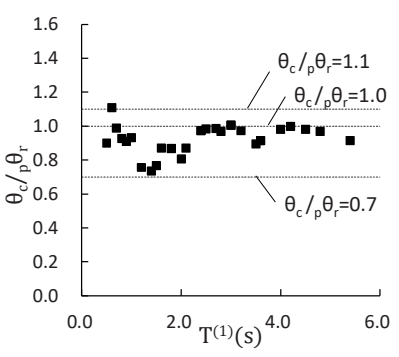

(d) $\mathrm{h}^{(1)}=0.10$
Fig. 17 Comparison between analytical and proposed uniform drift angle

\section{8. 一様層間変形角の目標値を実現する剛性設定法}

7 章(1)で一様変形角となるモード形状の設定を行い、7 章(2)では 応答変形角の予測法を示した。これらの結果をもとに、一様な層間
変形角を前提として目標とする応答層間変形角の值を実現する建 物剛性の設定方法を示す。

Step0 建物諸元（階数、階高、重量）を設定する。

Step1 目標とする一様な層間変形角を元に(19)式から固有周期お よび、減衰定数を設定する。

Step2 階数、固有周期、減衰定数をもとに、(10)式に示すモード 形を求め、(14)式から建物剛性を算出する。

一様変形を仮定すると、各階の変形角を求める必要がなく代表 変形にだけ着目すればよくなり、取り扱いが容易となる。

Step 1 での固有周期と減衰定数の設定では、組み合わせが無数に 存在する。グラフ化を行うと、固有周期と減衰定数による傾向を把 握しながら、見通しの良い設定が可能となる。具体例を 9 章に示す。 また、層間変形角から層間変形を求め、Step2で得られた剛性に掛 けることで、応答せん断力の予測も可能となる。

\section{9. 一様層間変形角の目標値を実現する検討例}

ここでは、22 階建て、高さ $92 \mathrm{~m}$ の鉄骨造の建物を考える。建物 重量、各階の階高は Table1 に示寸通りであり、各階で最小值に対し 重量は $20 \%$ 、階高は $37.5 \%$ の変動を有している。一様変形を仮定し て(17)式から求められる代表高さ $H_{r}$ は $63.0 \mathrm{~m}$ である。

固有周期 $T^{(1)}$ と減衰定数 $h^{(1)}$ をパラメータとして (19)式から求め た ${ }_{p} \theta_{r}$ を Fig.18に示す。層間変形角 $1 / 120(=0.0083)$ を目標とし、Fig. 18 より固有周期 $T^{(1)}$ を $3.22(=0.035 H)$ 秒とし、減衰は制振構造を考え 減衰定数 $h^{(1)}=0.05$ の剛性比例型減衰と設定する。

階数 $n$ と正規化した高さ $\widehat{H}_{j}$ から(10)式で求められた $\hat{u}_{j}^{(1)}$ おび、 固有周期と減衰定数を用いて(14)式から剛性 ${ }_{p} k_{j}$ を求めた。

一方、 5 章で示した時刻歴応答解析により制御された剛性を ${ }_{c} k_{j}$ とし、この結果得られた層間変形角を ${ }_{c} \theta_{j}$ とする。ここで、地震動 は 7 章と同じ 6 波とし、収束の判定基準は(9)式と同じとした。

Table 1 Parameters of

the analytical model

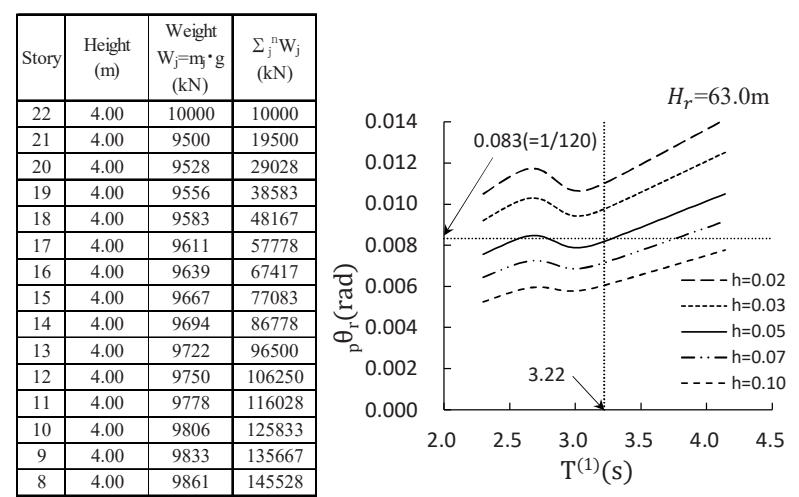

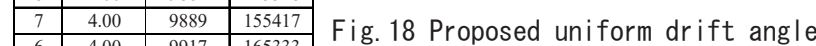

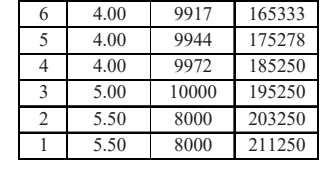

Fig.19(a)に ${ }_{p} k_{j}$ と ${ }_{c} k_{j}$ の比較を示す。 ${ }_{p} k_{j} /{ }_{c} k_{j}$ の最大の差異は $5 \%$ 程 度であり、良好な対応結果である。Fig.19(b)に、剛性 ${ }_{p} k_{j}$ を用いて時 刻歴応答解析で得られた層間変形角 ${ }_{a} \theta_{j}$ と ${ }_{c} \theta_{j}$ を示す。 ${ }_{a} \theta_{j} /{ }_{c} \theta_{j}$ の変 動は最大で $5 \%$ 程度である。また、 ${ }_{c} \theta_{j}$ の各層の平均值は $1 / 127$ であ 


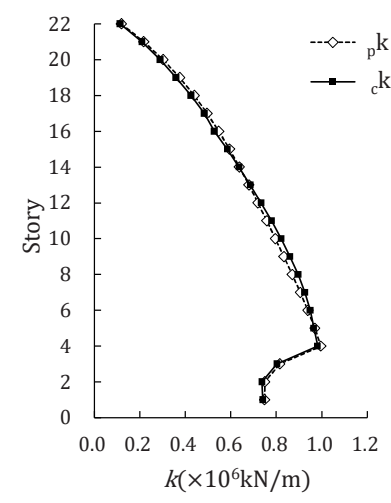

(a) Stiffness

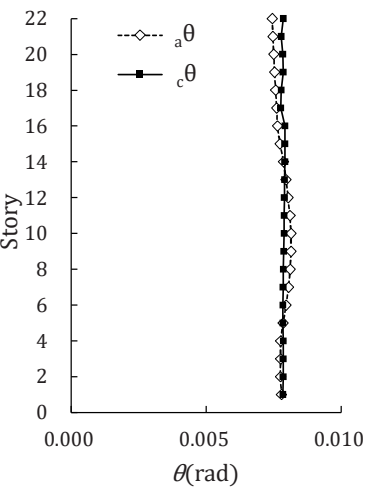

(b) Inter-story drift angle

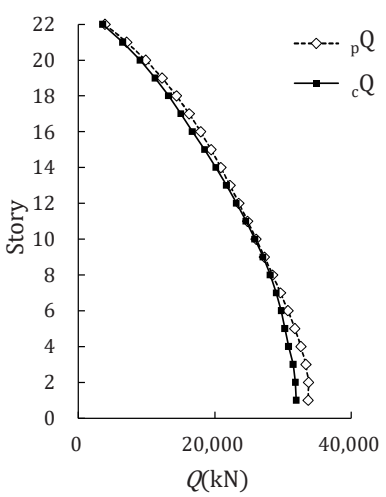

(c) Story shear force

Fig. 19 Comparison between analytical and proposed method

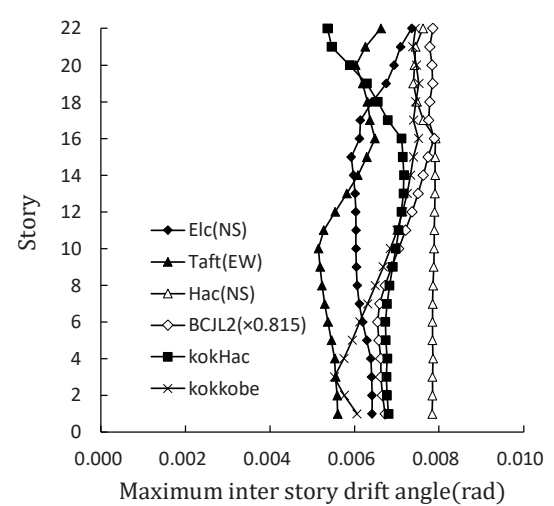

Fig. 20 Maximum inter story drift angle by stiffness ${ }_{c} k$
り、一方、(19)式から求めた ${ }_{p} \theta_{r}$ は $1 / 122$ である。 ${ }_{p} \theta_{r}$ は $4 \%$ 程度安 全側に評価した結果となっている。これは、Fig.17(b)に示される通 り $T^{(1)}=3.22$ では、 $\theta_{c} /{ }_{p} \theta_{r}$ が 1.0 以下にプロットされ、(19)式が安全 側の評価の領域となっているためである。

${ }_{p} \theta_{r}$ から求められる層間変形と剛性 ${ }_{p} k_{j}$ を掛けて求められるせん 断力 ${ }_{p} Q_{j}$ と制御後の応答せん断力 ${ }_{c} Q_{j}$ との比較を Fig.19(c)に示す。 最大 $9 \%$ 程度安全側に評価した結果となっている。Fig.20 に参考と して、制御後の各地震動の最大応答層間変形角を示す。各地震動共 に比較的一様な応答となっていることが確認できる。

質量および、階高が各階で変動する建物においても比較的精度 よく剛性の設定が可能であることが確認できた。設計初期の構造 計画を立案する前提で目標とする剛性をこの程度の誤差で設定で きれば、詳細設計により、最終的に一様変形を目標とする剛性の 調整も、大幅な構造計画の見直しをすることなく、比較的軽微な 対応で実現できるものと考えられる。

\section{0.まとめ}

本論では、地震時の層間変形角の一様化を目標とする剛性の設 定方法について考察を行った。主な内容は下記のとおりである。

1) 時刻歴応答解析結果に対し、一次モード形を更新調整するこ とにより、複数の地震動の最大応答值を包絡するような一様な 層間変形角応答を目標とする剛性の設定が可能であることを示 した。

2 ) 等質量、等階高の建物に対し建物層数、固有周期、減衰定数を パラメータとして、一様な層間変形角応答を目標とする剛性の制 御を 120 ケース行い、結果得られた一次モード形の形状分析を行 った。その結果得られた一次モード形に対し、建物層数、固有周 期をパラメータとする表現式を提案した。

3）120 ケースの解析結果から、建物代表高さ、固有周期、減衰定 数をパラメータとする一様変形角の推定式を示した。

4）2）、3）の結果より、一様な層間変形角を目標とし、一次モ ードを利用した繰り返し計算不要の建物剛性設定方法を示した。 また、質量変動、階高変動のある場合も、良好な剛性設定が可能 であることを確認した。

本論では、入力地震動は現状設計実務で用いられているものを 採用している。これらの地震動は、新たなる知見をもとに更新さ
れることも考えられる。その際には、一次モード形および層間変 形角の推定式の更新が必要となる。ただし、(10)式、(19)式のよう な表現式が得られれば、一様変形を目標とする剛性を簡易に算出 できる。本論で示した一次モード形をもとにする剛性の設定方法 は、耐震性向上を図る上で簡便でかつ有用であるものと考える。

一方、 5 章で示した一様な層間変形角を実現する剛性の制御方法 は、任意の地震動に対して数回の収束計算でそれほど大きな計算負 荷を伴わず精度の良い解が得られるというメリットがある。8 章で 示した手法の Step2 に 5 章の手法を適用し、(10)式を用いずに直接 的に剛性を求める方法も比較的容易であり、地震動の種類に限定さ れない汎用的な精算手法としても有用である。また、この方法では 任意の変形分布を指定することが可能である。

本論では建物モデルとして 30 層までを対象としている。高層建 物の場合、建物上部で曲げ変形の卓越が考えられる。本手法ではせ ん断型モデルとしており、曲げ変形を含めた等価せん断型モデルを 扱っていることになる。このモデルに本手法を適用することは、居 住性等の目的で曲げ変形を含めて各層一定の層間変形角とするよ うな目標設定に対応させたことになる。本論の目的の一つである建 物の強度バランスという観点で部分層崩壊等の弱点となる層を回 避するためには、建物の損傷に直接的に寄与寸るせん断変形を一様 にすることがふさわしいため、厳密にはその目的が果たされていな いことになる。曲げ変形成分の考慮、対応については今後の検討課 題である。

また、本論文は基本的な特性を把握する目的で，建物モデルを弾 性、減衰は剛性比例型減衰の簡易的な設定としている。実務設計に おいては，弾塑性応答、およびそれに伴う瞬間剛性比例型減衰，各 層の耐力分布といった要因も層間変形角の応答に大きく影響する。 これらの影響についても今後の課題となる。

\section{参考文献}

1) Kasai, K., Ito, H. and Ogura, T.: Passive control design method based on tuning of equivalent stiffness of bilinear oil damper, Journal of Structural and Construction Engineering (Transactions of AIJ), No.630, pp.1281-1288, 2008.8 (in Japanese)

笠井和彦, 伊藤浩資, 小椋崇之：オイルダンパーの等価剛性調節による 制振構造の応答制御手法, 日本建築学会構造系論文集, 630, pp. 1281$1288,2008.8$

2) Japanese Society of Seismic Isolation: Passive seismic response control structure design and construction manual, 2005 (in Japanese) 
日本免震構造協会:パッシブ制振構造設計・施工マニュアル編集委員, 2005

3) Suzuki, M.: Consideration of first mode shape control in nonproportional damping structure, Summaries of Technical Papers of Annual Meeting, Architectural Institute of Japan, Structures- I , pp.381-382, 2018.7 (in Japanese)

鈴木光雄: 非比例減衰構造の一次モード形の制御に関する考察、日本建築 学会大会学術講演梗概集, 構造 I, pp.381-382,2018.7

4) Nakamura, T., and Yamane, T.: Optimum design and earthquake response constrained design of elastic shear buildings, Earthquake engineering \& structural dynamics 14.5, pp.797-815, 1986.9/10

5) Wu, C. and Nishikawa, T.: Study on a method of elasto-plastic seismic response constrained design -For shear stiffness and strength distribution-, Journal of structural engineering. B, Vol.44B, pp.191-200, 1998.3(in Japanese)

呉誠, 西川孝夫: 構造物の弾塑性応答制御法に関する研究-せん断剛性お よび耐力分布について-, 構造工学論文集.B, Vol.44B, pp.191-200, 1998.3

6) Shibata, A.: Latest Earthquake-resistant Structural Analysis, Morikita Publishing Co. Ltd., 1981 (in Japanese)

柴田明徳：最新耐震構造解析、森北出版、1981

7) Ishiyama, Y. : Seismic Code and Structural Dynamics, Sanwa Syoseki Publishing Co. Ltd., 2008 (in Japanese)

石山祐二：耐震規定と構造動力学、三和書籍、2008

\section{付録 $\mathrm{A}$ 層間変形角一様化程度の変動について}

建物の一様変形の度合いを、各層の最大応答層間変形角の平均と標準偏差 の比で示される各層に関する変動係数 CV で表す。制御前後の CV の比 $\mathrm{CV}(\mathrm{Control} /$ Initial $)$ を縦軸、横軸を地震動としたグラフを 10 階、20 階、30 階 の建物について参考で Fig.A1 に示す。グラフ中 El Centro、Taft、Hac、 B_L2(81\%)、EN(Hac)、EN(Kobe)の表記は、地震波 El Centro1940(NS)、 Taft1952(EW)、Hachinohe1968(NS)、BCJ-L2（0.815 倍）および、告示波 (Earthquake in Notification, EN) の位相 Hachinohe1968(NS)、位相 JMA- Kobe 1995(NS)の結果である。全 720 回(=120 ケース $\times 6$ 波)の解析のうち 707 回で 1.0 以下となっており、応答值が小さく直接制御対象となっていない地震動

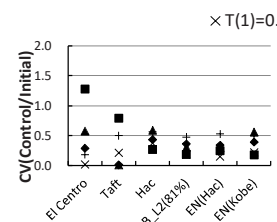

10 -story $(h=0.02)$
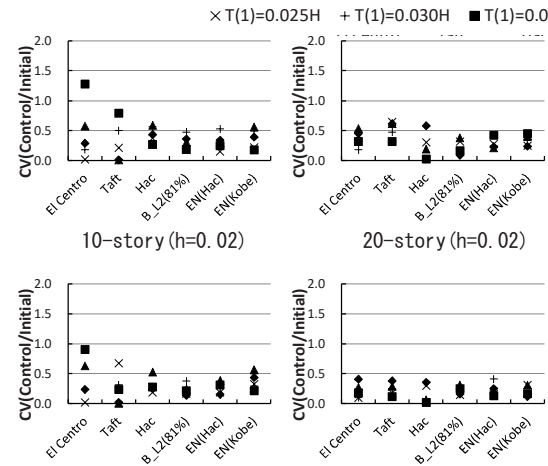

20 -story $(h=0.02)$
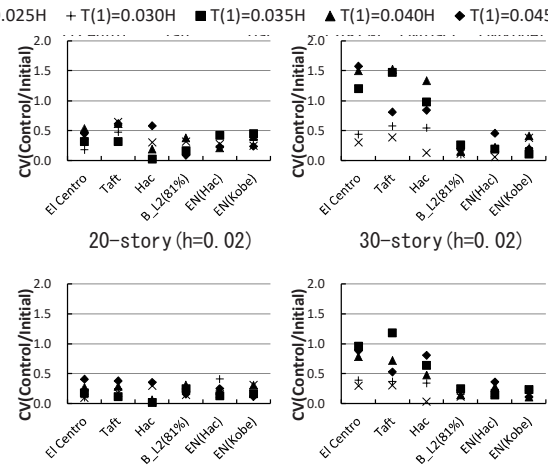

30 -story $(h=0.02)$
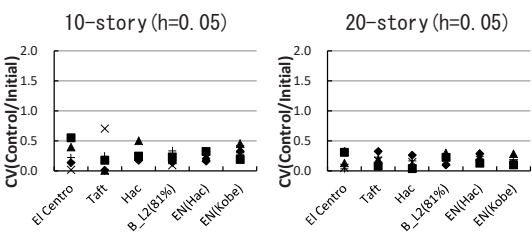

20-story $(h=0.07)$

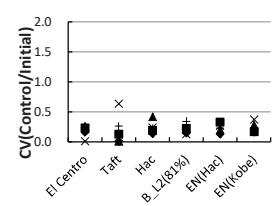

10 -story $(h=0,10)$

30 -story $(h=0.05)$

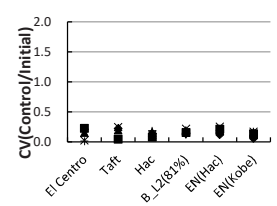

20 -story $(h=0.10)$
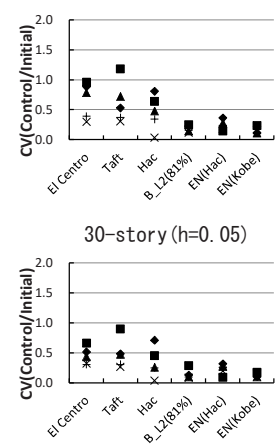

30 -story $(h=0.07)$

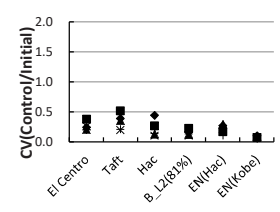

30 -story $(h=0.10)$
Fig. A1 Coefficient of variation in response of uniform drift angle
の応答においても、一様変形となる傾向が伺える。この傾向は、減衰が高く なるほど顕著である。

1.0 を上回るケースはいずれも観測地震動の El Centro1940(NS)、Taft1952 (EW)、Hachinohe1968(NS)の場合である。Fig.A2 に各地震の応答変位スペク トル $S_{d}\left(h^{(1)}=0.02,0.05\right)$ と、1.0 を上回るケースが生じた周期をプロットす る。ここで示したものが 1.0 を上回る全ケースに相当する。概ね長周期領域 で、周期に対する応答変位の増加割合が低く相対的にフラットな領域に分布 しており、他の地震動に比べ一次モードの影響割合が相対的に低いことが、 一様化の程度が向上しなかった一因と考えられる。

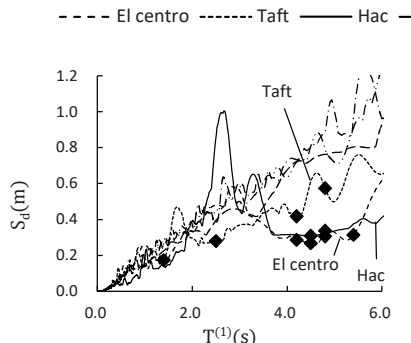

(a) $\mathrm{h}^{(1)}=0.02$
(Kobe) - Case where $\mathrm{CV}$ (control/original) $>1.0$

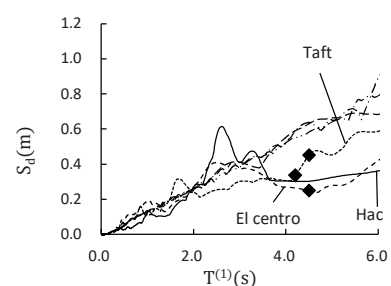

(b) $\mathrm{h}^{(1)}=0.05$
Fig. A2 Explanation by displacement response spectrum

付録 B （10) 式の構成について

(10)式では、一次モードの形状を三つの項で表している。第一項は、高さ 方向に直線状に分布するもので各層の変形勾配が一定の状態を示す。本文で 考察した高次モードの影響のうち、上部への影響を第二項で表し、中間部か ら最下部までの影響を第三項で示している。これらの影響を理解するために、 下図に第二項、第三項および第二項と第三項の和のグラフを示す。

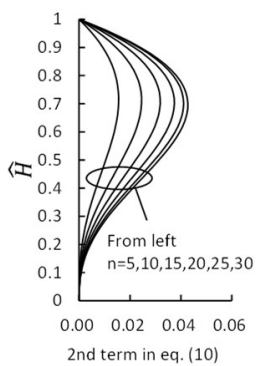

(a) 2nd term

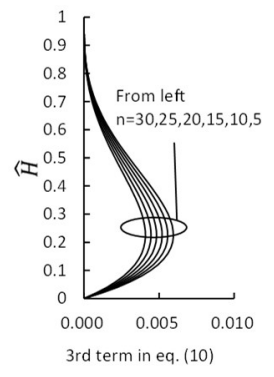

(b) $3 r d$ term

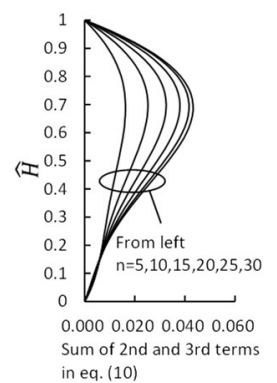

(c) Sum of two terms
Fig. B1 2nd and 3rd terms in eq. (10)

\section{付録 C 剛性算出時の補正係数}

$p \hat{u}^{(1)}$ から求められる剛性は、Fig.15 からもわかるように建物上部で変動 が大きくなる。これは、(2)式にモード成分の累積項があり、局所的なuの変 動の影響が建物下部では薄まり剛性の変動に表れ難いが、建物上部は累積の 割合が少ないため、局所的なuの変動に敏感に剛性が変動するためである。

一方、建物上部では減衰定数が低いと建物下部に比べ応答が大きくなる傾向 があり、減衰定数が高いと建物上部の応答は建物下部に比べ応答が小さくな る。よって、一様変形となるためには、減衰が小さい場合は建物上部の剛性 を大きくし、減衰が増えるにつれ、建物上部の剛性を小さくする必要がある。 20 層建物について減衰定数ごとに (10)式の $p \hat{u}_{j}^{(1)}$ を用いて(2)式から求め られる剛性 ${ }_{p} k$ と、一様変形となるように制御した剛性 ${ }_{c} k$ との比 ${ }_{p} k /{ }_{c} k$ を Fig.C1 に示寸。この傾向は、他の階数の建物も同様である。ここで、 $\widehat{H}=1.0$ での ${ }_{p} k /{ }_{c} k$ の平均值を $h^{(1)}$ ごとに求め、 $\widehat{H}=0.7$ で ${ }_{p} k /{ }_{c} k=1.0$ とし、直線補 完した近似係数を設定し、(2)式で求められた剛性にその逆数を掛けて補正を 行う。その補正係数を $r_{k}$ とし、算出する剛性を下式に示す。

$$
\begin{aligned}
{ }_{p} k_{j}^{\prime} & =r_{k}\left(\omega^{(1)^{2}} \sum_{l=j}^{n} m_{l} \cdot{ }_{p} \hat{u}_{l}^{(1)}\right) /\left({ }_{p} \hat{u}_{j}^{(1)}-{ }_{p} \hat{u}_{j-1}^{(1)}\right) \\
r_{k} & = \begin{cases}1 /\left\{\left(9.0 h^{(1)}-0.5\right)\left(\widehat{H}_{j}-0.7\right)+1\right\}, & \widehat{H}_{j} \geq 0.7 \\
1 \quad, & \widehat{H}_{j}<0.7\end{cases}
\end{aligned}
$$

この式を用いて各ケースに対し $\max \left|{ }_{p} k^{\prime}{ }_{j} /{ }_{c} k_{j}-1.0\right|$ で精度を評価した場合 
のヒストグラムを Fig.C2(a)に示す。また、補正係数 $r_{k}$ を用いない場合のヒス トグラムを Fig.C2(b)に示す。補正係数 $r_{k}$ を考慮するとばらつきが小さく精度 が良いことが確認される。

ただし、 $r_{k}$ を考慮すると固有周期にずれが生じること、また、上部に与え る影響は上部の局部的な減衰の影響と考えられるが、本論では建物全体の減 衰定数で評価していることから、この効果を評価しない方針とする。

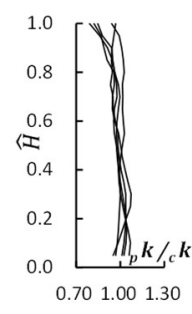

(a) $\mathrm{h}^{(1)}=0.02$

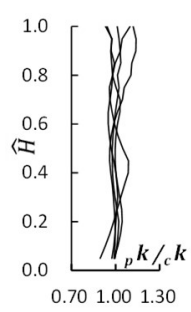

(b) $h^{(1)}=0.05$

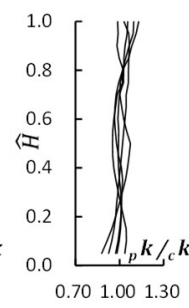

(c) $\mathrm{h}^{(1)}=0.07$

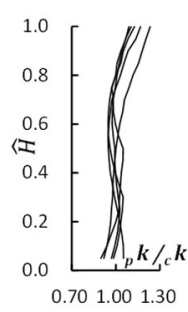

(d) $\mathrm{h}^{(1)}=0.10$
Fig. C1 Comparison between analytical and proposed stiffness for uniform inter-story drift angle (20-story)

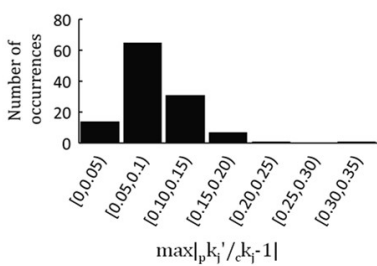

(a) With correction coefficient $r_{k}$

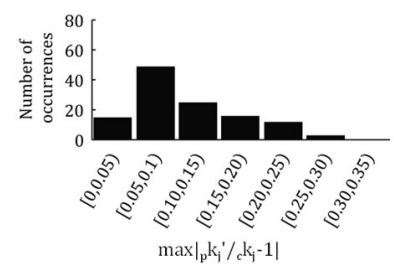

(b) Without correction coefficient $r_{k}$
Fig. C2 Accuracy of stiffness

\section{付録 D 層間変形角のばらつきについて}

(18)式の $y_{r}$ に(16) 式の ${ }_{p} y_{r}$ を適用した層間変形角 ${ }_{p} \theta_{r}^{\prime}\left(={ }_{p} y_{r} / H_{r}\right)$ を Fig.17 と同様に Fig.D 1 に示寸。固有周期 3.0 秒以上では 1.0 以下となるが、 3.0 秒以 下では、ばらつきが大きく 1.0 を超えるものが多くなっている。これは、Fig.16 に示されているように $y_{r}$ のばらつきが大きいことに起因する。本論は、設計 初期段階で計画案作成を目指寸ものであり、詳細検討での建物剛性の調整を 前提としている。ここでは、あまりに過剩に安全側とならない程度の精度と して、2.7 秒付近の特異に乘離しているものを除き応答解析結果が+10〜-30\% に収まるように補正を行ったものを(19)式として設定した。

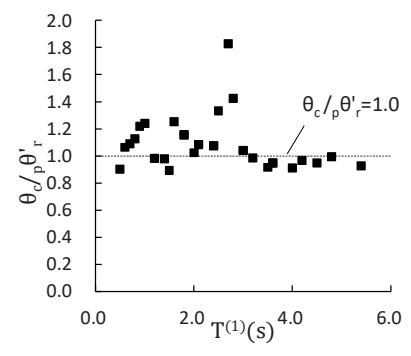

(a) $\mathrm{h}^{(1)}=0.02$

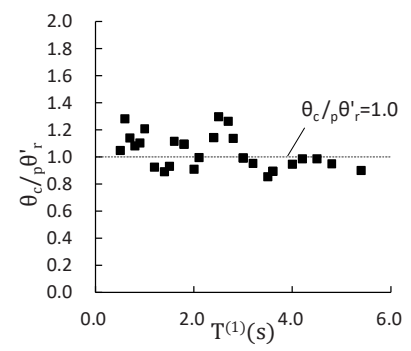

(c) $\mathrm{h}^{(1)}=0.07$

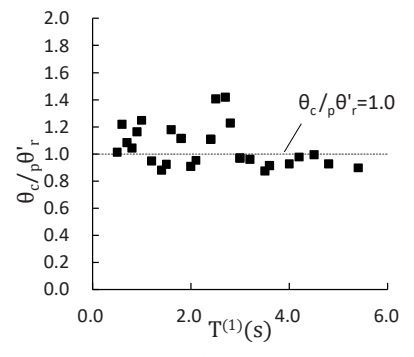

(b) $\mathrm{h}^{(1)}=0.05$

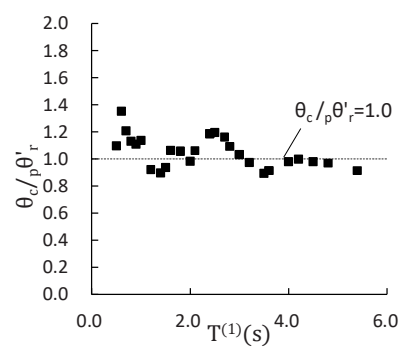

(d) $\mathrm{h}^{(1)}=0.10$
Fig.D1 Comparison between analytical and proposed inter-story drift angle without correction coefficient

\section{付録 $\mathrm{E}$ 代表変位の特異値について}

Fig.E1 に 7 章で解析した代表変位（プロット）と各地震動の応答変位スペ クトル（線）を重衩て示寸（地震動の凡例表示は付録 $\mathrm{A}$ と同じ）。代表変位 は一質点の応答変位と比較的よく対応する。短周期では代表変位は応答変位 スペクトルを概衩包絡し、周期 3 秒以上では高次モードの影響で応答変位ス ペクトルを上回る傾向が確認できる。7 章で見られたような代表変位が 2.7 秒付近で大きくなっているのは、Hachinohe1968(NS)の応答変位スペクトルが 特異に卓越しているためである。

- 5-story $\Delta$ 10-story $\bullet$ 15-story $\square$ 20-story $\triangle 25$-story $\diamond$ 30-story

- - - - El centro -...-..- Taft — Hac - - B_L2(81\%) - - - EN(Hac) - - - EN(Kobe)

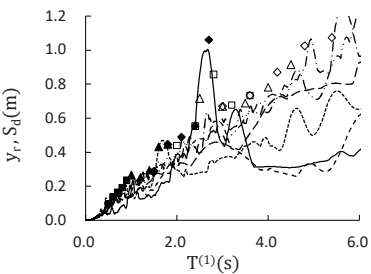

(a) $\mathrm{h}^{(1)}=0.02$

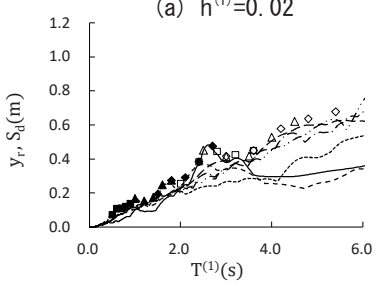

(c) $\mathrm{h}^{(1)}=0.07$

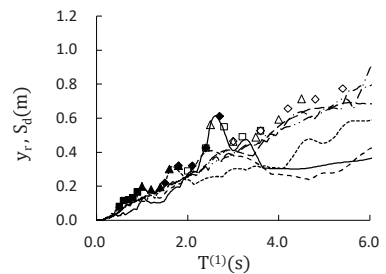

(b) $\mathrm{h}^{(1)}=0.05$

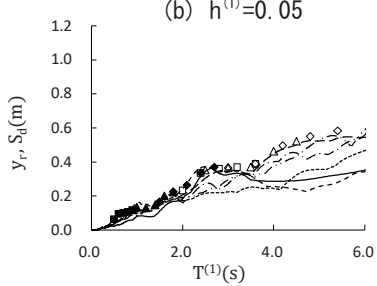

(d) $\mathrm{h}^{(1)}=0.10$
Fig. E1 Representative displacement and displacement response spectrum

\section{付録 $\mathrm{F}$ ベースシア係数の傾向について}

参考として、7 章の解析結果のベースシア係数について、横軸を周期とし て Fig.F1に示す。2.7 秒付近で Hachinohe1968(NS)により特異に卓越している 部分を除き、(F-1)式によりベースシア係数が包絡される結果となっている。 (F-1)式は簡便な表現としており、層間変形角設定の(19)式よりも安全側の設 定としている（(19)式は 2.7 秒付近以外でも $10 \%$ 程度上回ることを許容して いる）。9 章の解析例の最大応答ベースシア係数は 0.151 であり、(F-1)式では 0.171 と算出され $14 \%$ 程度安全側の評価となっている。

$$
C_{0}=0.2 h^{(1)^{-0.4}} T^{(1)^{-1.15}}
$$

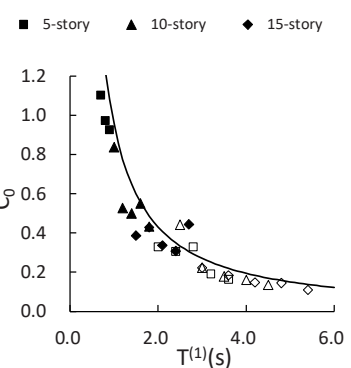

(a) $\mathrm{h}^{(1)}=0.02$

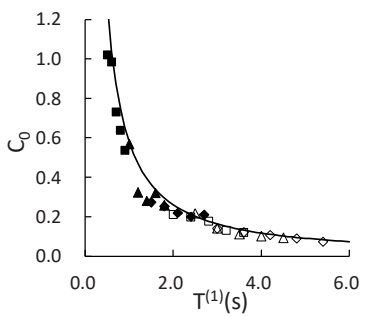

(c) $\mathrm{h}^{(1)}=0.07$

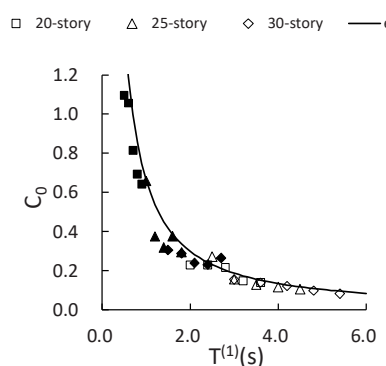

(b) $\mathrm{h}^{(1)}=0.05$

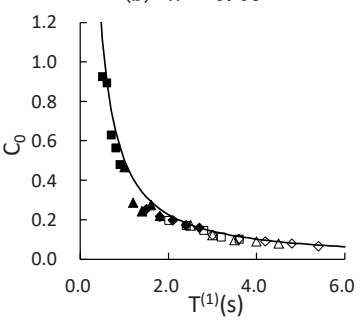

(d) $\mathrm{h}^{(1)}=0.10$
Fig. F1 Base shear coefficient 


\title{
STIFFNESS DETERMINATION METHOD UNIFORMIZING ENVELOPED INTER-STORY DRIFT ANGLE IN MULTIPLE SEISMIC RESPONSES
}

\author{
Mitsuo SUZUKI ${ }^{* 1}$ \\ ${ }^{1}$ Yamashita Sekkei Inc., Structural Design Dept., Dr.Eng.
}

Uniform inter-story drift angle in seismic response of buildings is effective in improving structural performance. Because it is expected to prevent pancake collapse due to concentration of deformation, and to decrease the maximum inter-story drift angle by efficient absorption of damping energy in each story.

In this paper, inter-story drift angle is controlled by stiffness calculated using the closed-form representation of a primary mode, and the method is applied with the results of time history analyses. Then the primary mode shapes are obtained from the results of time history analyses on 120 model cases, and the values of maximum inter-story drift angle are investigated.

The conclusions are obtained as follows.

1) It is possible to realize the uniform inter-story drift angle even in responses that envelop the maximum response values for multiple earthquake responses, by adjusting and updating the stiffness obtained from primary mode shape.

2) Primary mode shapes for uniform inter-story drift angle are shown with number of building stories and dimensionless height as parameters.

3) An equation for estimating the uniform inter-story drift angle is shown with building representative height, natural period, and damping constant as parameters.

4) From the results of 2) and 3), a simple method determining the building stiffness that realizes uniform inter-story drift angle is shown.

The presented method does not require repeated calculations. Therefore, this method is useful at the initial design stage.

In addition, the method of adjusting the stiffness to achieve uniform inter-story drift angle, which is shown in 1) above (see Chapter 5), has the advantage that an accurate solution can be obtained in a few convergence calculations for arbitrary seismic motion without much computational load. The direct use of this method is also useful. Furthermore, it is possible to specify an arbitrary deformation distribution with this method. 